\title{
Comparative Study of Gelatinization Kinetics of Some Edible Tubers
}

\author{
${ }^{1}$ Samuel, Goodnews Asuquo, ${ }^{2}$ Ntinya, Mbuotidem Usen and ${ }^{3}$ Akata, Nsidibe Inyang \\ ${ }^{1}$ Arthur Jarvis University, Akpabuyo, Nigeria \\ ${ }^{2}$ Department of Pure and Applied Chemistry, University of Calabar, Calabar, Nigeria. \\ ${ }^{3}$ Department of Environmental Resource Management, Abia State University, Uturu, Abia State, Nigeria. \\ DOI: 10.29322/IJSRP.11.11.2021.p11906 \\ http://dx.doi.org/10.29322/IJSRP.11.11.2021.p11906
}

\begin{abstract}
The kinetics of water gelatinization reaction in some edible tubers (Manihot esculenta, Colocasia esculenta, Dioscorea alata, Ipomoea batatas, Solanum tuberosum, Dioscorea dumetorum and Dioscorea rotundata) was investigated using a thermostated water bath at various temperatures. At $60{ }^{\circ} \mathrm{C}$, Manihot esculenta (ME) gelatinized in 125 min; Solanum tuberosum (ST), Dioscorea dumetorum (DD) and Dioscorea alata (DA), gelatinized in 140, 165 and 180 mins respectively but there was no gelatinization for Colocasia esculenta (CE) Ipomoea batatas (IB) and Dioscorea rotundata (DR) at this temperature. At $90{ }^{\circ} \mathrm{C}$ however, ME gelatinized in $2.00 \mathrm{~min}$ while ST, DD, DA, $\mathrm{DR}, \mathrm{CE}$ and IB showed gelatinization in 3.20, 5.00, 6.50, 7.30, 8.50 and 10.20 mins respectively. The rate of gelatinization of starch was found to be directly proportional to the gelatinization temperature and inversely proportional to the time of gelatinization'. A rapid gelatinization rate was observed for $\mathrm{ME}$ with the least gelatinization time $\left(\mathrm{G}_{\mathrm{t}}\right)$, IB on the other hand showed a much higher $G_{t}$ indicating its slow rate of gelatinization $\left(G_{r}\right)$. The rate of gelatinization was observed to follow the order: ME > ST $>\mathrm{DD}>\mathrm{DA}>\mathrm{DR}>\mathrm{CE}>\mathrm{IB}$.
\end{abstract}

Index Terms- gelatinization kinetics; retrogradation; starch; edible tubers.

\section{INTRODUCTION}

$\mathrm{A}_{\mathrm{c}}^{\mathrm{p}}$ part from being a principal staple food in Nigeria, tubers constitute a major source of carbohydrate used in the food, drug and textile industries. However, there is a depth of information on the gelatinization of local starches which form the major source of starch for these industries. It is our view that the information reported here will enhance knowledge on the gelatinization of starch.

Califano and Garcia, (2008), worked on the gelatinization of Mung bean (Vigna radiate) starch and concluded that the high activation energy obtained at low temperatures may be as a result of gradual disruption of inter- and intra- molecular hydrogen bonding chains.

Sandhu and Singh, (2007), reported on the gelatinization of starch among other things and concluded that amylose was positively correlated to hardness and gumminess of starch gels. Turhan and Gunasekaran, (2002), using the gelatinization of hard and soft wheat starches concluded that in situ and in vitro processes were first-order kinetic reactions.
Some studies were also carried out on potatoe tubers. Galkowska, (2008) examined the effect of saccharides on gelatinization and retrogradation of modified potato starch while Sharpe, (2004) explored their effects on gelatinization of rice and potatoe starches. They concluded that water uptake by rice did not have a linear relationship with time.

The goal of this research work is to investigate the rate/degree of gelatinization of cassava (Manihot esculenta), cocoyam (Colocasia esculenta), water yam (Dioscorea alata), sweet potato (Ipomoea batatas), Irish potato (Solanum tuberosum), trifoliate yam (Dioscorea dumetorum) and white yam (Dioscorea rotundata).

\section{MATERIALS AND METHODS}

The seven edible tubers listed above were purchased from the farmers market in Marian Road, Calabar Municipality, Calabar, Nigeria.

The reagents used were potassium iodide, sodium chloride (Analytical grade) and distilled water (solvent).

\subsection{Preparation of Sample}

The sample was carefully chosen, peeled, washed with distilled water and sliced into tiny stripes of about 2.5 to $5.0 \mathrm{~mm}$ thickness. Each was dried in a Griffin and George thermostated oven (model 1/200) at $60{ }^{\circ} \mathrm{C}$ for about twenty-four hours (to constant weight), ground with an electric blender (QLink, model QBL-15L40) and sieved with $0.43 \mathrm{~mm}$ mesh sieve to give fine flour.

The prepared samples were individually placed in air tight containers, labeled and stored at $23-25^{\circ} \mathrm{C}$.

2.2. Analysis of sample

The method used by Sharpe, (2004) was modified and utilized for gelatinization of the starch sample. The sample (30 g) was mixed with $100 \mathrm{ml}$ distilled water with stirring for homogeneity. This was placed in a thermostated water bath at the required temperature. The stirring continued at an average rate of about 85 rotations per minute. Readings were taken at specific time intervals and recorded. The gelatinization temperatures (GT) as well as the gelatinization time $(\mathrm{Gt})$ were noted for each of the food samples.

The ratio of the concentration of ungelatinized starch to the time of gelatinization gave the apparent rate of gelatinization. The actual gelatinization rate indicated the increment in torgue at $1{ }^{\circ} \mathrm{C}$ 
rise in temperature (Perry and Donald, 2002). This was determined by comparing the concentration of the ungelatinized starch with the time of gelatinization.

\subsection{Rate of gelatinization}

For the determination of the rate of gelatinization, $30 \mathrm{~g}$ of the sample was mixed with $100 \mathrm{ml}$ of distilled water with stirring. The mixture was immersed in a thermostated water bath at a specific temperature. An aliquot of $10 \mathrm{ml}$ of the reaction mixture was taken at specific time intervals. This was then immersed in an ice bath to quench the reaction and titrated against a $0.01 \mathrm{M}$ solution of potassium iodide. A blue-black colouration indicated the end point. Eight readings were taken for each run at each temperature; The readings were used to determine the concentration of ungelatinized starch using the formulae:

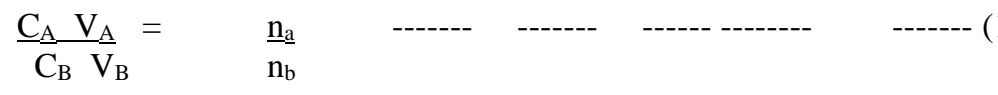

Where: $C_{A}=$ Concentration of potassium iodide (in moles per $\mathrm{dm}^{3}$ )

$\mathrm{V}_{\mathrm{A}}=$ Volume of potassium iodide (in $\mathrm{ml}$ )

$C_{B}=$ Concentration of ungelatinized starch (in moles per $\mathrm{dm}^{3}$ )

$\mathrm{V}_{\mathrm{B}}=$ Volume of ungelatinized starch (in $\mathrm{ml}$ )

$\mathrm{n}_{\mathrm{a}}=$ Mole ratio of potassium iodide

$\mathrm{n}_{\mathrm{b}}=$ Mole ratio of ungelatinized starch.

The rate of gelatinization was determined by comparing the concentration of ungelatinized starch with the time of gelatinization.

The apparent rate of gelatinization $\left(\mathrm{R}_{\mathrm{A}}\right)$ was determined from the concentration of ungelatinized starch using the equation: $\mathrm{R}_{\mathrm{A}}=\underline{\mathrm{c}}$

Where: $R_{A}$ is the apparent rate of gelatinization,

$\mathrm{c}$ is the concentration of ungelatinized starch, $\mathrm{t}$ is Time in minutes.

\section{RESULTS AND DISCUSSION}

Gelatinization properties of the samples

The gelatinization time for the samples at various temperatures is presented in Table 1. There was no significant gelatinization for $\mathrm{CE}, \mathrm{IB}$ and $\mathrm{DR}$ at $60{ }^{\circ} \mathrm{C}$ but they showed a relatively high gelatinization at elevated temperatures at nearly equal time intervals (See figure 1), but at $1 \mathrm{~min} \mathrm{ST}$, IB and $\mathrm{CE}$ demonstrate ungelatization at $0.02 \mathrm{~mol} / \mathrm{L}, 0.025 \mathrm{~mol} / \mathrm{L}$ and 0.035 $\mathrm{mol} / \mathrm{L}$ respectively (see figure 2 ). This shows that some edible tubers require high temperature for bond breakage and agrees with work done by Salomon and Buchholz, (2000) in their kinetic studies. As earlier mentioned, Turhan and Gunasekaran, (2002), observed that the degree of gelatinization increased with time for all the food samples they studied. The starch of the root tuber, ME, easily dispersed in water, was more soluble and had the highest gelatinization value compared with the stem tubers. This is probably the reason it is used more in the industries especially in the textile industry as cloth starch. On the other hand, the stem tubers such as CE, DA, IB, ST, DD and DR contain mucilage that binds them together, thus, they were not easily dispersed in water and, required more energy to break the inter-molecular hydrogen bonding that exists within them. This agrees with the observations of Agbanyin, et al., (2014). This might be why they showed significant gelatinization at higher temperatures.

TABLE 1

Gelatinization time of samples at various temperatures.

\begin{tabular}{llllllll}
\hline $\begin{array}{l}\text { Temp. } \\
\left(\begin{array}{l}\left.{ }^{\circ} \mathbf{C}\right) / \mathbf{s a m} \\
\text { ples }\end{array}\right.\end{array}$ & ME & CE & DA & IB & ST & DD & DR \\
\hline 60 & 125. & No & 180. & No & 140. & 165. & No \\
70 & 00 & gel. & 00 & gel. & 00 & 00 & gel. \\
80 & 30.0 & 65. & 56.3 & 75. & 40.8 & 48.5 & 60. \\
90 & 0 & 00 & 0 & 20 & 0 & 0 & 20 \\
& 4.50 & 23. & 12.5 & 28. & 6.80 & 8.00 & 20. \\
& 2.00 & 30 & 0 & 00 & 3.20 & 5.00 & 40 \\
& & 8.5 & 6.50 & 10. & & & 7.3 \\
& & 0 & & 20 & & & 0
\end{tabular}

From the foregoing, it can be deduced that the gelatinization time is dependent on the type of starch being gelatinized. This was also observed by Sopade, et al., (2004). It follows a first-order reaction kinetics and obeys the Clausius-Clapeyron type equation.

This observation supports the predictions made by Turhan and Gunasekaran, (2002), on in situ and in vitro gelatinization of hard and soft wheat starches and whole durum wheat during cooking.

The starch of ME gelatinized faster than the others, thus it had the shortest gelatinization time. The longest gelatinization time was observed for IB. 


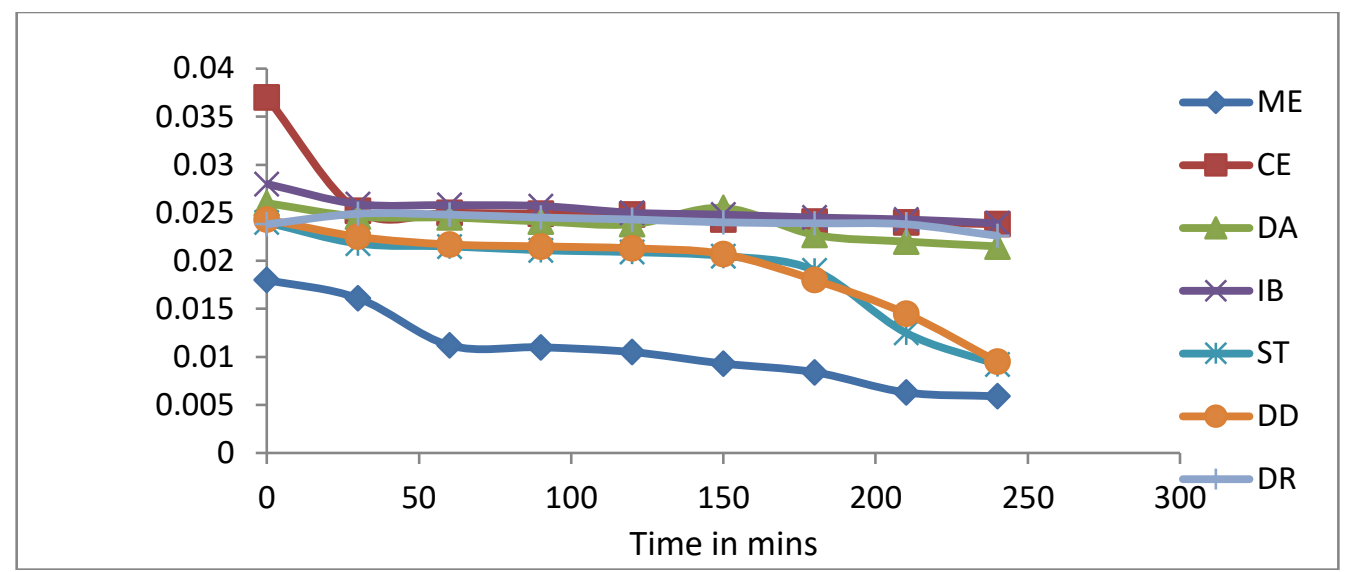

Fig. 1: Variation of concentration of ungelatinized starch with time for the samples at $60{ }^{\circ} \mathrm{C}$.

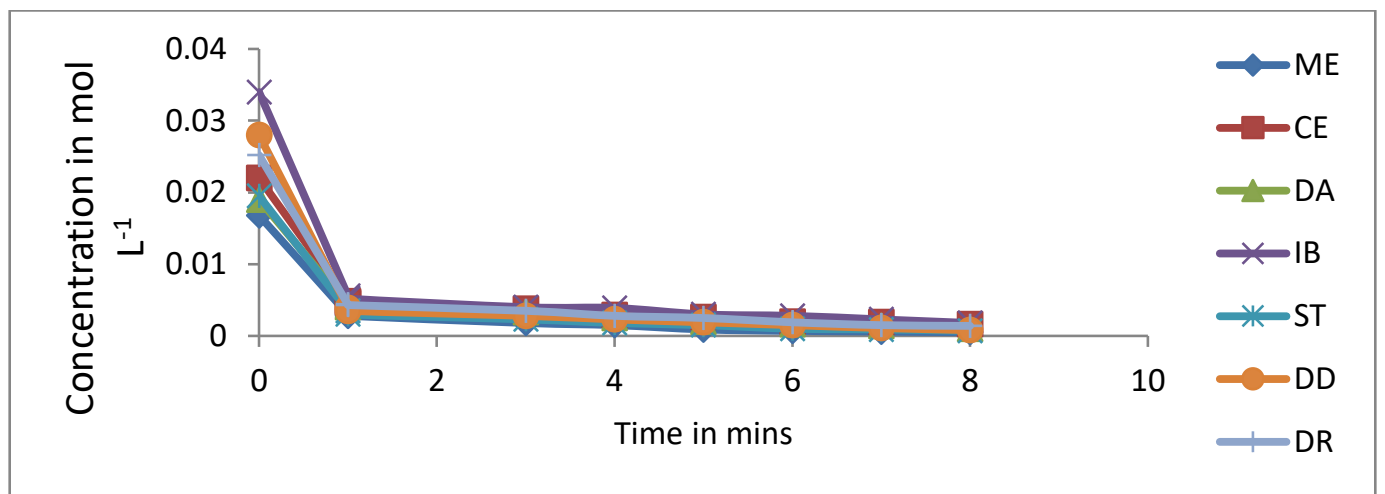

Fig. 2: Variation of concentration of ungelatinized starch with time for the samples at $90{ }^{\circ} \mathrm{C}$.

The gelatinization rate expresses the increment in torgue during one minute of $1{ }^{\circ} \mathrm{C}$ temperature rise. The kinetic studies for the samples at the temperature of $60{ }^{\circ} \mathrm{C}$ and 30 mins time interval is shown in Table 2 .

TABLE 2

Kinetic studies on Manihot esculenta,Colocasia esculenta, Dioscorea alata, Ipomoea batatas, Solanum tuberosum, Dioscorea dumetorum and Dioscorea rotundata at $60{ }^{\circ} \mathrm{C}$

$\begin{array}{lllllllllllllll}\begin{array}{l}\text { G } \\ \text { (mins) }\end{array} & \text { ME } & \text { CE } & \text { DA } & \text { IB } & \text { ST } & \text { DD } & \text { DR } & \text { ME } & \text { CE } & \text { DA } & \text { IB } & \text { ST } & \text { DD } & \text { DR } \\ \mathbf{0} & 18.0 & 37.0 & 26.0 & 28.0 & 24.0 & 24.3 & 23.8 & \text { NA } & \text { NA } & \text { NA } & \text { NA } & \text { NA } & \text { NA } & \text { NA } \\ \mathbf{3 0} & 16.1 & 25.2 & 24.6 & 25.9 & 21.8 & 22.5 & 24.9 & 5.37 & 8.40 & 8.20 & 8.63 & 7.27 & 7.50 & 8.30 \\ \mathbf{6 0} & 11.2 & 25.0 & 24.5 & 25.8 & 21.5 & 21.7 & 24.8 & 1.87 & 4.17 & 4.08 & 4.30 & 3.58 & 3.62 & 4.10 \\ \mathbf{9 0} & 11.0 & 24.9 & 24.1 & 25.7 & 21.1 & 21.5 & 24.5 & 1.22 & 2.77 & 2.68 & 2.86 & 2.34 & 2.39 & 2.70 \\ \mathbf{1 2 0} & 10.5 & 24.8 & 23.8 & 25.0 & 20.9 & 21.3 & 24.3 & 0.88 & 2.07 & 1.98 & 2.08 & 1.74 & 1.77 & 2.03 \\ \mathbf{1 5 0} & 9.30 & 24.3 & 25.5 & 24.8 & 20.5 & 20.7 & 24.0 & 0.62 & 1.62 & 1.70 & 1.65 & 1.37 & 1.38 & 1.60 \\ \mathbf{1 8 0} & 8.40 & 24.1 & 22.7 & 24.5 & 19.0 & 18.0 & 23.9 & 0.47 & 1.34 & 1.26 & 1.36 & 1.06 & 1.00 & 1.33 \\ \mathbf{2 1 0} & 6.30 & 24.0 & 22.0 & 24.3 & 12.5 & 14.5 & 23.8 & 0.30 & 1.14 & 1.05 & 1.16 & 0.60 & 0.69 & 1.13 \\ \mathbf{2 4 0} & 5.90 & 23.8 & 21.5 & 23.9 & 9.20 & 9.51 & 22.6 & 2.46 & 1.00 & 0.80 & 1.00 & 0.38 & 0.40 & 0.94 \\ \mathbf{A} & 4.20 & 20.2 & 19.4 & 22.0 & 7.00 & 7.90 & 19.2 & \text { NA } & \text { NA } & \text { NA } & \text { NA } & \text { NA } & \text { NA } & \text { NA }\end{array}$

$\beta_{0} \times 1^{-3}\left(\mathrm{~mol} \mathrm{dm}^{3-1}\right)$

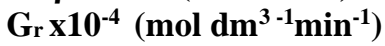

From the results, it was observed that the gelatinization rate decreased with increase in time but increased with increasing concentration (see table 2). This justifies the claims of Turhan and Gunasekaran, in 2002, that the rate constant increased with cooking temperature. The rate was known to be kinetically pseudo first-order and, obeys the Arrhenius model
The results for gelatinization rate were also obtained for temperature range of 70,80 , and $90^{\circ} \mathrm{C}$ at various time intervals and is expressed in figure 3.

The gradient of the curves gave the actual (true) rate of gelatinization of the food samples. A higher gelatinization rate was observed for $\mathrm{ME}$, whereas, $1 \mathrm{~B}$ showed a much lower gelatinization rate compared to the former. The rate of gelatinization was known to follow the trend: $1 \mathrm{~B}<\mathrm{CE}<\mathrm{DR}<$ 


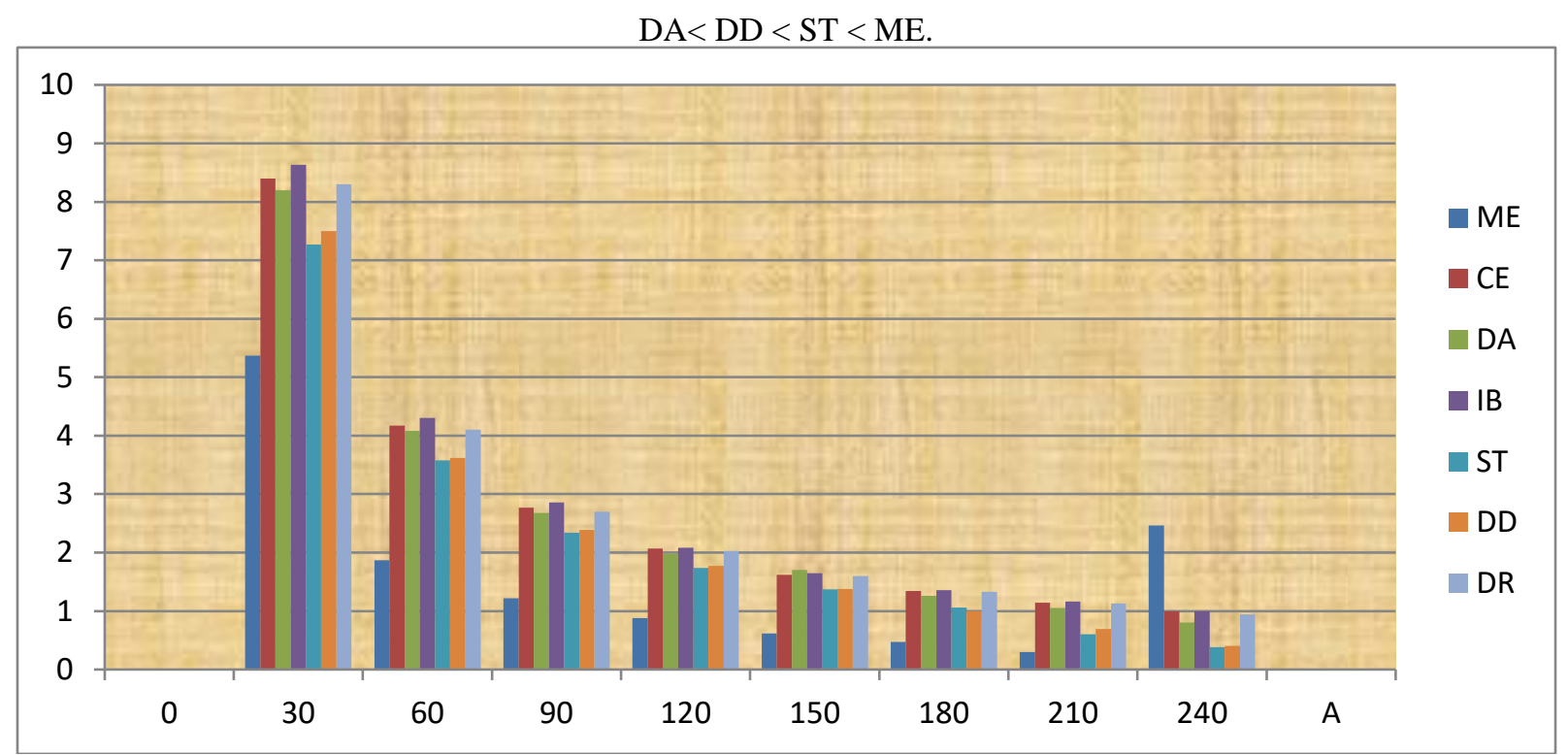

Fig. 3: Variation of the gelatinization rate of the samples at different temperature

\section{CONCLUSION}

The observed kinetics of gelatinization of some edible tubers used in this research confirms that certain factors such as gelatinization time, concentration of ungelatinized starch and gelatinization temperature influence the rate of gelatinization. Apparent starch gelatinization and gelatinization rate are both irreversible processes but the former is a first-order reaction while the later is kinetically pseudo first-order. The reaction rate constant was also known to vary directly with the gelatinization temperature.

\section{REFERENCES}

[1] Aee, L. H., Hie, K. N. \& Nishinari, K. (2008). Differential scanning calorimetry and rhelogical studies of the effects of sucrose on the gelatinization and retrogradation of corn starch in thermochemistry. Journal of Food Engineering, 322(1), 39-46.

[2] Agbanyin, A. N., Onukwube, N. D., Okoro, O. A. \& Brown, N. (2014). Comparative study of ethanol production from plant tubers and cereal, Dioscorea dumetorum, Ipomoea batatas and Sorghum bicolour. Uyo, 37th Annual International Conference, Workshop and Exhibition of Chemical Society of Nigeria, 37(1), 118.

[3] Ahmed, F. B. \& Williams, P. A. (2009). Effects of sugars on thermal and rheological properties of sago starch in biopolymer. Journal of Food Engineering, 50(1), 401-412.

[4] Atkins, P. \& Paula, J. D. (2006). Physical chemistry. Oxford, Oxford University Press. 335pp.

[5] Baek, M. H., Yoo, B. \& Lim, S. T. (2004). Effects of sugars and sugar alcohols on thermal transition and cold stability of corn starch gel in food hydrocool. Journal of Food Engineering, 18(1), 133-142.

[6] Bakshi, A. S. \& Singh, R. P. (2008). Kinetics of water diffusion and starch gelatinization during rice parboiling, Journal of Food Science, 45(1), 1387 1392.

[7] Bean, M. N. \& Yamazaki, W. T. (2004). Wheat starch gelatinization in sugar solution and its microscopy and viscosity effects. Journal of Cereal Chemistry, 55(6), 936-944.

[8] Belitz, H. D., Grosch, W. \& Schieberle, P. (2004). Some properties of starch. Journal of Food Chemistry, 185(3), 318-323.
[9] Biliaderis, C. G., Page, C. M., Maurice, J. J. \& Juliano, B. O. (2004). Thermal characterization of rice starches and polymeric approach to phase transitions of granular starch. Journal of Agriculture, 34(1), 6-14.

[10] Birch, G. G. \& Priestley, R. J. (2003). Degree of gelatinization of cooked rice. Journal of Food Engineering, 25(1), 98-100.

[11] Buck, J. S. \& Walker, C. E. (2008). Sugar and sucrose ester effects on maize and wheat starch gelatinization patterns by differential scanning calorimeter. Journal of Food Engineering, 40(9), 353-356.

[12] Cabrera, E., Pineda, J. C., Duran, D. C., Segurajauregeui, J. S. \& Vernon, E. J. (2004). Kinetics of water diffusion and starch gelatinization during corn nixtamalization. Journal of Food Engineering, 52(1), 117-125.

[13] Califano, A. N. \& Garcia, M. E. (2008). Determination of geletinization kinetics of mung bean (Vigna radiata) starch by several dynamics differential scanning calorimetric methods. Argentina. Centro de Investigacion y Desarrolo en Criotecnologia de Alimentos (CIDA) CONICET. Fac. De Ciencias Exactas, Universidad Nacional de La Plata, 12(1), 22-24.

[14] Cauvain, S. P. \& Young, L. S. (2001). Baking problems solved. Cambridge. Woodhead Publishing.143pp.

[15] Chungcharoen, A. \& Lund, D. B. (2004). Influence of solutes and water on rice starch gelatinization. Journal of Food Engineering, 64(4), 240-243.

[16] Clark, J. (2013). Orders of reaction and rate equation. http://www.chemguide.co.uk. 22/03/2014.

[17] Coral, D., Pineda-Gomez, P., Rosales-Rivera, A. \& Rodriguez-Garcia, M. (2009). Determination of the gelatinization temperature of starch presented in maize flower. Journal of Physics. 167(1), 2057.

[18] Daryl, B. L. (2007). Food engineering and physical properties. Journal of Food Science, 72(1), 405-475.

[19] Donald, E. P. (2006). New wheat starches on the horizon. Journal of Food Technology, 60(4),51-60.

[20] Dosunmu, M. I. \& Agu, R. A. (2000). A comparative study of the effects of method of preparation on ascorbic acid and sugar contents of some Nigerian leafy green vegetables. Natural and Applied Science Transactions, 2(1), 2934.

[21] Dosunmu, M. I. \& Ekerendu, E. (2002). Chemical composition and functional properties of Mucuna sloanei seed. Global Journal of Pure and Applied Chemistry, 6(1), 23-26.

[22] Dosunmu, M. I. (2001). Chemical composition and functional properties of Musa sapientum (cooking banana) flour. Natural and Applied Science Transactions, 3(1), 65-69.

[23] Evageliou, V., Richardson, R. K. \& Morris, E. R. (2000). Effects of sucrose, glucose and fructose on gelatinization of oxidized starch. Journal of Polymer science, 42, 261-272. 
[24] Evans, J. D. \& Haisman, D. R. (2002). The effects of solutes on the gelatinization temperature range of potato starch. Journal of Food Engineering, 34(7), 224-231.

[25] Furtuna, T., Gakowsk, D. \& Juszezak, L. (2004). Comparison of rheological properties of selected preparations of modified starches. Acta Science Polymer Technology Aliment, 3(1), 21-32.

[26] Galkowska, D. (2008). Effect of saccharides on gelatinization and retrogradation of modified potato starch. Journal of Agriculture, 1(2), 181183.

[27] Grider, J. (2006). State of the industry report and breakfast cereals in the United States of America. Cereals Food World, 41(1), 484-487.

[28] Hart, P. E. \& Blanshard, J. M. (2002). The effects of extraction method upon the gelatinization behaviour of wheat starch granules. Journal of Food Engineering, 34, 293-296.

[29] Henry, R. J. \& Waters, D. L. (2008). Gelatinization temperature manipulation. Rural Industries Research and Development Co-orporation. Southern Cross University, 1(3), 16

[30] Hoseney, R. C. (2004). Scanning electron microscopy of starch isolated from baked products with principles of food science and technology Cereals Food World, 22(2), 56-60

[31] Jacobson, M. R., Obanni, M. \& Bemiller, J. N. (2007). Retrogradation of starch from different botanical sources. Journal of Food Engineering, 74(5), 511-518.

[32] Jang, J. K., Lee, S. H., Cho, S. C. \& Pyun, Y. R. (2001). Effect of sucrose on glass transition, gelatinization and retrogradation of wheat starch. Journal of Food Engineering, 78(2), 186-192.

[33] Jankowski, T. \& Rha, C. K. (2005). Studies on cooking process of wheat grain by differential scanning calorimetry in conjunction with the physical properties of agricultural materials and their influence on design and performance of agricultural machines and technologies. Journal of Agriculture, 1(1), 383-388.

[34] Kawaljit, S. S. \& Narpinder, S. (2006). Some properties of corn starches II: Physicochemical, gelatinization, retrogradation, pasting and gel textural properties. Journal of Food Chemistry, 101(9), 1499-1507.

[35] Kim, C. S. \& Walker, C. E. (2002). Effects of sugars and emulsifiers on starch gelatinization evaluated by differential scanning calorimetry. Journal of Food Engineering, 69(2), 212-217.

[36] Kohyama, K. \& Nishinari, K. (2001). Effects of soluble sugars on gelatinization and retrogradation of sweet potato starch. Journal of Agriculture, 39(1), 1406-1410.

[37] Kubota, K. (2007). Studies on the gelatinization rate of rice and potato starches. Journal of Food Science, 44(1), 1394-1397.

[38] Lund, D. B. \& Wirakartakusumah, M. (2006). A model for starch gelatinization phenomena and engineering science in the food industry. Journal of Food Engineering, 2(1), 425-432.

[39] Maaurf, A.G., Che Man, Y. B., Ashi, B.A, Junaihah, H. \& Kennedy, J. (2001). Gelatinization of Sago starch in the presence of sucrose and sodium chloride as assessed by differential scanning calorimetric. Journal of Polymer Science, 45(40), 335-345.

[40] Molina, I. R., Cortez, E. G., Fonseca, A. P., Banos, L., Pons-Hernandez, S. H., Guzman-Macdonado, P., Pineda-Gomez, M. E. \& Rodrigues-Garcia, M. E. (2007). Study of the changes in the endosperm of quality protein maize during traditional nixtamalization process. Cereal chemistry. Journal of Food Engineering, 84(4), 304-312.

[41] Morah, F. N. I. (2010). Science, industrial and traditional importance of the Nigerian palm-wine. Calabar Journal of Liberal Studies, 10(2), 103-107.

[42] Morphy, P. (2000). "Starch". Handbook of hydrocolloids. Boca Raton, Woodhead Publishing. 115pp.

[43] Ojeda, C. A., Tolaba, M. P. \& Suarez, C. (2000). Modeling starch gelatinization kinetics of milled rice and potato flour. Journal of Food Engineering, 77(1), 145
[44] Okechukwu, P. E. \& Roa, M. A. (2001). Kinetics of cowpea starch gelatinization based on granule swelling. Journal of Food Engineering, 48(1), 43-47.

[45] Onuchukwu, A. I. (2006). Chemistry of surface \& colloid. Ife, Ambix Printers.126pp.

[46] Parker, R. \& Ring, S. G. (2001). Aspects of the physical and food chemistry. Journal of Cereal Science, 34(1), 1-17.

[47] Perry, P. A. \& Donald, A. M. (2002). The effect of simple and complex sugars on the gelatinization of starch. Journal of Polymer Science, 49(1), 155-156.

[48] Resio, A. C. \& Suarez, C. (2001). Gelatinization kinetics of amaranth starch. International Journal of Food Science and Technology, 36(4), 441-448.

[49] Salomon, M. \& Buchholz, F. (2000). Effects of temperature on the respiration rates and the kinetic of citrate synthase in two species of Isopoda crustacea. Journal of Molecular Biology, 125(1), 71-81.

[50] Sandhu, K. S. \& Singh, N. (2006). Some properties of corn starches I Physicochemical, gelatinization, retrogradation, pasting and gel textural properties. Journal of Food Science, 101(7), 1499-1507.

[51] Savage, H. L. \& Osman, E.M. (2008). Effects of certain sugars and sugar alcholos on the swelling of corn starch granules. Journal of Cereal Science, $55(1), 447-454$

[52] Sharpe, K. (2004). Gelatinized starch investigation on the effects of heat and water on starches. Journal of Food Engineering, 56(3), 56-82.

[53] Shashi, C. (2003). A Textbook of Engineering Chemistry. New Delhi, Educational and Technical Publishers. 287pp.

[54] Sopade, P. A., Halley, P. J. \& Junming, L. L. (2004). Gelatinization of starch in mixtures of sugars by application of differential scanning calorimetry. Journal of Polymer Science, 58(1), 311-321.

[55] Stapley, A. G., Hyde, T. M., Gladden, L. F. \& Fryer, P. J. (2007). Nuclear Magnetic Resonance imaging of the wheat grain cooking process. International Journal of Food Science and Technology, 32(1), 355-375.

[56] Tester, R. F., Debon, S.J., Davies, H. V. \& Gidley, M. J. (2009). Effect of temperature on the synthesis, composition and physical properties of potato starch in food agriculture. Journal of Science, 79(14), 2045-2051.

[57] Torley, P. J. \& Van der, M. F. (2005). Gelatinization of starch in mixed sugar systems. Journal of Food Technology, 38(7), 762-771.

[58] Turhan, M. \& Gunasekaran, S. (2001). Kinetics in situ and in vitro gelatinization of hard and soft wheat starches during cooking in water. Journal of Food Engineering, 52(2), 1-7.

[59] Walrzburg, M. S. (2006). Modified starches, properties and uses. Boca Raton, CRS press. 232pp.

[60] Wang, Y. J. \& Wang, L. (2003). Physicochemical properties of common and waxy corn starches oxidized by different levels of sodium hypochlorite. Journal of Polymer Science, 52(3), 207-217.

\section{AUTHORS}

First Author - Samuel, Goodnews Asuquo, Arthur Jarvis University, Akpabuyo, Nigeria

Second Author - Ntinya, Mbuotidem Usen, Department of Pure and Applied Chemistry, University of Calabar, Calabar, Nigeria.

Third Author - Akata, Nsidibe Inyang, Department of Environmental Resource Management, Abia State University, Uturu, Abia State, Nigeria.

Corresponding Author: Ntinya, Mbuotidem Usen

Email: muntinyachem@gmail.com 
International Journal of Scientific and Research Publications, Volume 7, Issue 8, August 2017 